\title{
DEVELOPMENT JOURNALISM AND ITS POTENTIAL CONTRIBUTION TO THE STATE BUILDING: THE CASE OF SOMALIA
}

\author{
ISMAIL SHEIKH YUSUF AHMED \\ QATAR UNIVERSITY
}

\begin{abstract}
Development aspect is a key target and agenda for all governments in the world. The concept embraces different facets of development including political, social, economic, infrastructure, societal, environmental, and intellectual aspects. Numerous factors contribute to the achievement of the above goals. Among these is a communication policy factor; an effective and comprehensive policy can help the state accelerate development success rate. In underdeveloped countries, the mass media play an essential role in mediating the development in the country. Systematic and comprehensive communication policies are greatly needed in these countries compared to developed and developing countries. In Somalia, where there was no effective and functioning state since 1990s, the need for such policies is great. The country has been in chaotic and unstable political situation, where the media has negatively contributed to hostility and conflict. In this paper, the author discusses the concept of development journalism and its evolution and relevance particularly to the newly independent states in Asia and Africa since 1960s. Although some people may argue that, the concept is out of date; this author believes that it is more relevant in today's current political dilemma in Somalia. The paper provides numerous rationales for adopting the development journalism and how it can contribute to the state building efforts. Implications for policy and decision-makers were also discussed along these lines. For media practitioners, the paper recommends to follow peace journalism when covering tribal and political conflicts and to fully participate in current development projects.
\end{abstract}

Keywords: Development journalism, peace journalism, potential, contribution, communication policy.

\section{KEWARTAWANAN PEMBANGUNAN POTENSI SUMBANGAN NYA PADA PEMBANGUNAN NEGARA: KES SOMALIA}

\begin{abstract}
Abstrak
Secara global, aspek pembangunan adalah kunci dan agenda utama kebanyakan negara. Konsep ini merangkumi pelbagai aspek pembangunan termasuk politik, ekonomi, infrastruktur, masyarakat, alam sekitar dan intelek. Beberapa faktor menyumbang pada pembangunan arah tuju tersebut. Antaranya ialah faktor polisi komunikasi, satu polisi yang berkesan dan menyeluruh yang mampu membantu memecut tahap kejayaan pembangunan. Dalam negara yang belum membangun, media massa memainkan peranan sebagai perantara pembangunan negara. Polisi komunikasi yang sistematik dan menyeluruh amat di perlukan di negara yang belum membangun ini di bandingkan dengan negara membangun dan sedang membangun. Sehubungan ini, negara Somalia amat memerlukan polisi ini kerana keadaan komunikasi dalam negara ini tidak berkesan dan tidak beroperasi sejak tahun 1990an. Keadaan politik negara ini kucar kacir dan tidak stabil


dan media telah menymbang secara negatif kearah pertelingkahan dan konflik. Kertas kerja ini membincangkan kewartawanan pembangunan dan evolusi serta kerelavanannya khusus pada negara yang baru merdeka di Asia dan Afrika sejak tahun 1960an. Walau ada yang mempertikaikan bahawa konsep ini sudah lapuk namun penulis yakin ia relevan dalam situasi politik semasa Somalia. Kertas kerja ini memaparkan beberapa rasional untuk menggunapakai kewartawanan pembangunan dan bagaimana ia boleh menyumbang pada usaha pembangunan negara. Implikasi terhadap polisi dan pembuatputusan juga dibincangkan dalam konteks ini. Kertas kerja ini menyarankan pengamal media mengamalkan kewartawanan aman apabila membuat liputan konflik politik dan suku kaum dan melibat diri sepenuhnya dalam pembangunan projek semasa.

Kata kunci: Kewartawanan pembangunan, kewartawanan aman, potensi, sumbangan, polisi komunikasi.

\section{INTRODUCTION}

Somalia has been experiencing chaotic situations since the collapse of the central government in 1991. This led to lose all the important infrastructures in many key sectors. A civil war broke out among Somali tribes and new warlords emerged who have divided the country into small lands or parts. There were many attempts to restore peace, stability, and system in the country. Almost all those efforts failed to bring the desired goals- to restore the system, due to many different reasons. Since 1991, four transitional governments had been formed in Kenya and Djibouti, two neighboring countries to Somalia. To have stable and effective government in the country, the international community has organized several conferences for Somali political parts. Several approaches have been followed since then and there were many suggestions to follow among others a bottom-up approach in order to get permanent solutions to the big challenges (Upsall, 2014). The goal of those transitional governments is to prepare general elections, formulate the final draft of the constitution, and to restore order in the country. In September 10, 2012, the transitional period has ended with the presidential elections, which was described as "ever first fair and democratic elections" since 1967 (Smith, 2012). A new president, from the civil society, 
has been elected. Several challenges are head of the newly elected government including restoring the order, fostering security, and development of the country. The communication element has been emphasized in efforts and policies of all previous governments. If the government is serious about overcoming these challenges, it is imperative to give full attention to the potential to the role of mass media in this regard. As argued by McPhail (2009), political, economic, social and other life aspects can be achieved through development communication strategy. Using this strategy, the mass media can be fully utilized in achieving these goals.

To overcome the challenges facing by the country, the mass media should play an essential role in this vein. The role of mass media encompasses mobilizing the masses towards the governments' projects, persuading the people about the governments' intensions, and engaging them with the projects. In Somalia, the mass media, including the radio, had played a crucial role in both the development and the destruction of the country. As such, the aim of this article is to critically evaluate the applicability of development journalism approach to the Somali context. It reviews other contexts, which had adopted this approach and then provides several recommendations and suggestions. Since the country is approaching a new era of change, what are the advantages of this approach, which help formulate the philosophy of desired development in the country? How it can be adopted to the Somali context, since there are cultural and social perspectives between Somalia and the country origin of this theory? To answer these questions, we will be reviewing the literature, and then we shall advise on its applicability to the Somali context. 


\section{LITERATURE VIEW}

\section{Development journalism: Evolution and expansion}

Mass communication scholars have used the concept of development journalism since 1960s. Development journalism has been used interchangeably with development communication to mean the initiative led by the mass media to create change in many of the aspects of the life (Mefalopulos, 2009; Müller, Mitchell, \& Feek, 2007; Sparks, 2007). Development is an important aspect that every government should allocate a great time and efforts. More than 1.2 million people around the world are suffering from a serious poverty (Müller et al., 2007) and unstable political situations, which make their lives very difficult. The emphasis of the previous paradigm of the concept before three decades was the economic aspect (McPhail, 2009) while the new shift in the concept is inclusive of all aspects of the society with a particular focus on social and cultural facets.

Although it has been argued that development journalism is out of date, the concept has revived and prevalent in most developing countries where a huge task of development projects in undergoing (Bessette, 2004; Green \& Goetting, 2010; Odhiambo, 1991). The concept is grounded in the assumption that mass media including print, broadcast and the internet can be used as intervening process for making the development happen and visible in the eyes of the public (McPhail, 2009).

The concept has become popular among African governments, which took over the power from the colonials with the beginning of a new age of economic growth (Odhiambo, 1991; Skjerdal, 2011). According to Skjerdal (2011, p. 58), the concept has been adopted by various 
leaders by making some adjustment to their government systems including military, one-party democracy style, autocratic, and multiparty systems. Broadly speaking, the idea of this concept is that the journalism should play a great role in the country such as dissemination of government policies in order to create awareness among the public as well as mobilize them towards the implementation of these policies (Wong, 2004, p. 26). Edeani (1993, p. 126) defined the concept as "the kind of journalism which pays sustained attention to the coverage of ideas, policies, programs, activities, and events dealing with the improvement of the life of a people". The concept first emerged in Southeast Asia in the late 1960s, where it was used in Thompson foundation workshop in the Philippines in 1968 (Gunaratne and Hasim, 1996, cited in Skjerdal, 2011, p. 59). Skjerdal (2011) also argued that development journalism has its roots in revolutionary journalism, promoted by Ghana's first president, Nkruma, where he has used the various media to mobilize the people against the colonizers. In this regard, this concept was prevalent in almost all public addresses in 1970s.

Ogan (1982, p. 3) defined the development journalism as "a concept at the heart of this new information order. It appears that both the proponents and the critics of the establishment of this "new" kind of journalism are not clear about the concept's meaning or method of application in any particular setting". He used development journalism and development communication as interchangeable terms. He provided the background of the conflict over the term since 1970s when the United Nations Educational Scientific and Cultural Organization (UNESCO) declared to adopt the concept, in order to help the developing countries and address their many social and political challenges. He asserted that the groups who advocate for the press freedom have attacked the UNESCO, including the international press institute (IPI), and House freedom. He takes as an example, the UNESCO conferences in Latin America, where the experts suggested 
the idea of "nationalism". It means that the all types of media should be nationalized and should be government-controlled media, in order to focus more on the development of the nation.

The concept of development communication is not only used for mass media communication, but it encompasses all other communication channels. Ogan (1982) Ogan (1982) cited pioneers of the concept including Querbel of Philippines. She argued that "communication for development is not confined to the mass media channels, but includes any all effective means of communication- interpersonal face-to-face, small group, the stage play, a picture, or even billboard" (p. 7). In addition, Ogan described communication development as "purposive, persuasive, goal-oriented, audience-oriented, and interventionist by nature" (p. 7).

Far from the conventional debate about the concept, Ogan, (1982, p.8) Ogan $(1982$, p.8) contended that some authors prefer to describe the concept of development journalism as the "fifth theory of press", as a new theory, maintaining, that the "position of developing countries is such that journalists have never experienced quite the same relationship with their societies before". She argued that Siebert et. al's four theories of the press, is based on their assumptions about the social and political structures that the press operates in it. Thus, she has questioned whether development journalism is "a new form or forms or just a variation on the traditional four theories" (p. 8).

Ogan (1982) differentiated two conceptual meanings of the concept of development journalism/communication. Firstly, development support communication is "communication process used only to serve the development goals of the government in power" (p. 9). In this context, development journalism is defined to mean, "the critical examination, evaluation, and report of the relevance, enactment, and impact of development programs, demands that the mass media be independent of government" (p.9). However, she argued that the authoritarian is 
relevant and effective in this context. She quoted Lent (1977), who has provided rationales for government-controlled development journalism:

Because third world nations are newly emergent, they need time to develop their institutions. During this initial period of growth, stability and unity must be sought; criticism must be minimized and the public faith in governmental institutions and policies must be encouraged. Media must cooperate, according to this guided press concept, by stressing positive-inspired news, by ignoring negative societal or oppositionist characteristics and by supporting governmental ideologies and plans. (Lent, 1977, p. 18, cited in Ogan, 1982).

In this context, Ogan argued that this perspective is not different from an authoritarian perspective of press since it legislates the government control of the media. Furthermore, when the development journalism defined as evaluative or critical, it is consistent with the social responsibility theory of the press. However, Ogan concluded, "depending on one's definition of this "new" concept, development journalism belongs either to authoritarian or the social responsibility theory of the press. It is just another example of new wine in old bottles" (p. 11).

In another perspective, Banda (2007) explained that the concept of development journalism, particularly in the African context, could be discussed with reference to the historical evolution of the theory of development communication, especially the three historical paradigms. As he argued, the first paradigm is the "modernization" paradigm. This paradigm "dominated the period from 1945 to 1965 and stressed the transfer of the technology and socio-political culture of modernity from the developed North to the Third World. It found its coherent articulation in 
Everett M. Rogers's 'diffusion of innovations' perspective” (p. 155). The second paradigm is the "dependency-dissociation paradigm". This approach is "associated with the elevation of the aspirations of the newly independent nations of the Third World for political, economic, and cultural self-determination and an ideological distancing from Western forms of modernization" (p. 156). In line with this paradigm, Banda asserted that the developing countries including African and Asian newly independent states, had taken many initiatives.

These include the establishment of the non-aligned movement, which preferred not to be dragged to the cold war between the west and the former Soviet Union, as well as the establishment of Pan-African News Agency (PANA), which established by the organization of the African Union, in order to draw the attention of the international news to the voice of Africa and African peoples. The African states were disappointed on how the west press and news agencies cover the events of Africa and African people. They complained about the huge amount of negative news published or broadcast about African in major news corporations in the West. In this context, some African leaders have used the concept of "revolutionary theory of press" in 1960s. As Banda, (2007, p. 165) cited, the Nkrumah of Ghana "articulated this theory in 1963 during the second conference of African journalist. He told them that the "the truly African revolutionary press" existed in order to present and carry forward our revolutionary purpose, and establish a progressive political and economic system upon our continent". The third paradigm is "emancipator journalism". It is referred to as the "multiplicity" or "another development paradigm" (p. 157). Simply put, it meant participatory journalism. This paradigm considers cultural identity of locals. The concept emphasizes the value of democratization and participation at all levels. He concluded that the concept of development journalism "goes beyond 
'modernization' and 'dependency- dissociation' paradigms of development communication to embrace elements of participatory communication" (p. 168).

\section{ADOPTION OF DEVELOPMENT JOURNALISM BY AFRICAN STATES:}

The concept of development journalism is not new in terms of the African context. It has existed since 1960s, 1970s, and 1980s, especially when the newly born, independent African states started to develop their nations (Boafo, 1985; Odhiambo, 1991).

As noted by Boafo (1985), radio is considered the most popular communication technology used and adopted by African people. The radio was used to implement many projects in Africa such as health, education, and agriculture programs. Newspapers, television, and other media outlets were used to implement the "multimedia development-oriented projects" (p. 85). These projects were meant to address problems hindering the development by using a comprehensive communication strategy. Among these strategies is "Man is health campaign" that was launched in 1973 in Tanzania (p. 85). In order to have effective communication strategies for development, Boafo (1985) discussed several strategies to be followed by the policy makers:

1. Comprehensiveness of clarity of the roles and responsibilities of the communication in the society.

2. Facilitation of availability of suitable communication technologies that support decentralization, participation and incorporation of rural area's needs.

3. Adoption of both new and traditional media for accelerating development prerequisites and needs of the society. 
4. Integration of communication strategies to the other essential components such as social, economic, cultural and political programs.

5. Acknowledgement of the value of the information as an important national research, which reflects as production, processing and management for the benefit of the society particularly those in rural areas.

With regard to options of communication strategies, many diverse challenges face African states. As Domatob and Hall (1983) noted, it is up to them to face the many essential choices about their media development. They cited McBride (1979, P.32):

Communication can be instruments of power, a revolutionary weapon, a commercial product, or a means of education: it can serve the ends of either liberation, or either of oppression, of the growth of the individual personality, or of drilling human being into uniformity. Each society must choose the best way to approach the task facing us all and to find the means to overcome the material, social and political constraints that impede progress" (p. 32).

Specifically, let us look at the two development journalism models in two African countries: Ethiopia, a neighboring country to Somalia, and Nigeria, the most populated nation in the continent.

Skjerdal (2011) studied the adoption of development journalism in Ethiopia. Ethiopian authorities introduced "basis and directives for an operational philosophy of democracy and development media" in 2008. The document offered the journalists a great opportunity to comment on the draft. It consisted of 48 pages, covering the philosophical and operational terms. He pointed out that the main concern of the policy is about how to address the economic problems in the country. The most important element that frames the Ethiopian policy is 
economic poverty, in which the government strives to put the Ethiopian people among middleincome societies within 20-30 years.

Skjerdal (2011) argued that the document, philosophically, is based on the authoritarian and libertarian ideologies. He discussed the criticisms faced by these ideologies by pointing out that authoritarian was criticized for its strict control of the freedom of the people, whereas libertarian can be rejected for its main concern of profit rather than national interests. Thus, he sees the solution underlies in another approach, which lie middle of these ideologies. He defines this approach as a" development journalism philosophy". Finally, he concludes that the development journalism policy in Ethiopia is driven by poverty situation, since there is a severe poverty in the country. The concept "puts more trust in the state media than the private media when it comes to stimulating development..." (p. 67).

In another context, Edeani (1993) discussed the adoption of development journalism in Nigeria. He argues that adoption of the model in Nigeria begun in the half of 1980s, especially when the government launched "federal government's revolutionary rural development policy" in 1986 . The main aim of the policy was to ensure a comprehensive development of the rural areas in the country. In this context, Edeani differentiates three types of journalists when it comes to the coverage. Firstly, conventional journalist is "who reports on rural development issues with professional detachment and only a moderate commitment to the values of development journalism". Secondly, the development journalist is "who reports on rural development issues on an ad hoc basis with low commitment". Thirdly, also the development journalist is "who reports on rural development issues on a regular basis with professional devotion and 
responsibility, and who is strongly committed to the values of development journalism" (p. 141). He concluded that the "development journalism has a great potential for making real, lasting contributions to the rural and national development" (p. 141). Similarly, media was found to have contributed to important projects related to development such as peace building, conflict resolution, and reconciliation (Curtis, 2000).

\section{POTENTIAL ADVANTAGES OF DEVELOPMENT JOURNALISM FOR SOMALIA:}

In the literature above, we discussed the concept of development journalism, its definitions, underlying assumptions, and principles; how the countries adopted, and what consequences emerged in the adoption process of this model. In addition, we discussed the origin of the concept, and found that the concept is more and more relevant to African states when it comes to the media and its contribution to the development. Most of African countries, including Somalia, are suffering from conflict, poverty, and political instability.

In the Somali context, however, the concept of journalism is not a new phenomenon, although it was not clearly defined as others did. The practice of the concept is available, particularly during the period of the former military regime (1969-1991), which extensively used the term "development" and "revolutionary" in all its campaigns.

When it comes to media contribution in the development, we can refer to the many programs and campaigns that the government at that time implemented and how the "Radio Mogadishu", the only official radio in the country at that time, participated in mobilizing the public, stimulating and persuading them to engage in government programs and campaigns. Radio Mogadishu had extensively broadcast regular news, commentaries, articles, and interviews 
in Arabic language, as a part of government campaign to strengthen the Arabic language in the country (Barrow, 1988). Additionally, the radio had covered the events related to the campaign, interviewing the officials, and entertaining the public with poems, songs, and short stories in Arabic language. The main success that the radio and the government achieved is the writing down of the Somali language in 1972, and its dissemination among the urban and rural inhabitants. Radio Mogadishu had played a significant role in the campaign "read and write" which smoothly spread in all cities and rural areas. The Radio conducted public opinion polls and public mobilization towards the campaign and field studies in order to test the effectiveness of the campaign and how the public was interacting with it. Daily radio programs included "learn Somali language from the radio", "radio commentary", "poems" and "speeches of officials of the campaign" (Barrow, 1988).

Similarly, the older people or generation of 1960s and 1970s recall the effective campaigns that launched by the military regime. Those campaigns attracted the public to actively and voluntarily involve in the implementation of several projects. Those include "self-help" campaign, which helped the country build its main premises and government buildings including hospitals, schools, roads, industries, and some government offices. Those campaigns spearheaded by teachers, students, farmers, workers and civil society organizations (Ministry of Information and National Guidance (MING), 1974).

The concept of "revolutionary" which proposed by Nkrumah of Ghana, is also used by former Somali President General Mohamed Siad Barre. Even Barre used the concept extensively in almost all his addresses, since the government is based on military revolution. Thus, He and the government officials provided a "revolutionary" explanation for everything they discuss or 
address. After the collapse of the central government in 1991, the concept is more used in public addresses by emerging warlords.

Following the fall of the military regime, Somali media found absolute freedom. There were no regulations, restrictions, license, publication policy, government control and censorship, and even self-censorship. This can be called "absolute libertarian" press, where everybody can publish, broadcast, own radio or newspaper, criticize what he dislikes, and frames the news and events according to his own agenda. The media in this period participated in the civil war, which had a profound impact on all aspects of life. The fighting factions used the media as a "counterattack" technique. Some of tribes owned radio stations and newspapers, which they used as "white and black propaganda" against rival tribes by demonizing and distorting others' images and reputation.

At the beginning of this century, there were many attempts to restore the reputation of the media and repair its image among the public who have no trust any more with it. Many independent institutions emerged who provided extensive courses and training in journalism practices, ethics, and principles. Those institutions helped increase the awareness of the journalists and the public, which contributed to somewhat repair the media image in the country, even though skepticism towards media still exist.

Since the country is still experiencing political instability, there are several rationales for adopting development journalism by Somalia. We believe that the concept of journalism development can serve as a catalyst for a positive change in Somalia (Anand, 2014). We discuss the following points regarding the rationales of adopting this concept: 
1. Since 1991, the country has been in turmoil and politically instable, which led to lack of essential services of the government. The country has no effective and functioning central government, national army, police forces, and institutions of public service. However, if Somalia adopted the development journalism, it will help rebuild those institutions and public services, as it was built before with the help of the people in 1970s. Thus, the media is used to mobilize, persuade, and involve the public in a systematic way in all kinds of initiatives, be it donation, involvement or political support.

2. After two decades of civil war, Somalia is socially disintegrated, and there is a fierce hostility among Somali tribes. Thus, adopting this approach can help in reconciliation and forgiveness among the tribes, restoration of the properties to their owners, and giving compensations to the victims and their families. In this approach, the media only emphasize the social harmony, integration, and importance of peace to all parts. The media should avoid defamatory frames about tribes.

3. Since 2012 , there are no apparent progress made by the government regarding many social and political aspects. This due to unavailability of effective communication strategy, among others. The country is approaching a political change (elections in 2016) and thus, the government should present, through development journalism model, its policies and strategies of tackling many unsolved and controversial issues. The government should not use this model to achieve its own agendas, rather for development purposes.

4. The country is still suffering from civil war and its consequences. Although there is a federal national government, some quarters oppose the government, and refused all kinds of negotiations and talks. They were called upon many times for conferences, but still did not accept that, due to foreign interference and influence, particularly the Al-shabab group, 
which the media and western media framed them as "terrorist" group, and also described themselves as Al-qaeda in east Africa. However, effective communication strategy can help persuade those young men to choose the peace and be part of their community, thus forcing the foreigners to go back to their countries as well as expelling the extremist ideas. In this context, peace journalism is more relevant. The media should be sensitive when covering this group and similar groups.

5. The country is entirely destroyed by two decades of civil war. The government has huge task, which the development and reconstruction are the most important and challenge tasks ahead the government. Therefore, adopting effective development journalism model, the government can achieve many goals.

6. The country is suffering from serious drought, famine, inflation, and lack of economic services. The government should take many initiatives, including effective development journalism model in order to achieve it within short period. Through media, the government can address many social and political problems that exist in the country. Through effective and directed media, the government can negotiate with its oppositions; present its policies, goals, and achievements.

7. Somalia has long and historical hostility with the neighboring countries particularly Ethiopia and Kenya, which occupy large territories of Somali origin. Through effective communication strategy and effective diplomacy, the government should address these concerns since the two countries are still engaged directly and indirectly in what happened and still happening in the country. The government should follow all possible means peacefully in order to tackle these issues, and it is encouraged to continue the efforts of 
former prime minister of Somalia, Mohamed Ibrahim Igal, who believed that through diplomacy and public referendum, this issue can be resolved (Geddi, 2001).

8. Since the country was in civil war and chaotic situation, the rate of illiteracy is very high among Somalis. The government should address this issue and implement many campaigns like what former government did in 1970s and 1980s. Through media, all kinds of mass media including radio, television, and internet the government can succeed and achieve the goals.

\section{CONCLUSION}

The paper sought to critically investigate the applicability of development journalism concept to Somalia. Since the country is suffering from many social and political problems, the concept is relevant and applicable with minor revisions on the philosophical and operational aspects.

In order to adopt this approach (development journalism), the government should allow mixed ownership of media, with special focus on government-controlled media. It should formulate policies and restrict regulations for media practice, including licensing, punishment, editorial policy, censorship, and self-censorship. The government should implement effective policies regarding the increasing number of Radio and TV stations in the country. More than 20 Radio and TV stations operate only in the capital city, which reflects, in another way, a media chaos and distorted public sphere. A possible solution is to integrate some of these stations, which help produce more efficient media professionals. More restrictive measures for establishing a media organization should be implemented including experience and relevant qualification for media workers. 
Using Radio and TV drama, the mass media in the country can provide up to date information on government plans, policies and development projects. This is not new in the context of development journalism or communication and it has been used in numerous countries(Banda, 2007; Pate \& Dauda, 2013; Yusuf, Ibrahim, \& Aminah, 2012).

Development journalism education should be incorporated in the curriculum of communication programs offered in the universities in the country. To the best of the author's knowledge, there is no university providing such incorporation. Journalism education can offer the media practitioners in the country fundamental assumptions of this concept and how they can contribute to the development by employing it. Through this approach, they actively engage the public in development project and provide a positive image about it, which in turn gives hope to the public.

The government should increase the quality and quantity of the ministry of information, telecommunications, and post employees through constant training in order to serve better for the development of the country. Scholarships and internships are among possible ways of obtaining workforce with desirable capacity.

Within twenty or thirty years, the government should reach the desired and intended goals of development, then should allow socially responsible press, which can serve the community better, and critically evaluate and examine the government system in the country. The reason of delaying of this socially responsible press is that the whole system of governance is now missing. Thus, making any evaluation or scrutiny is useless. The adoption of development journalism should emphasis the definition of the concept as "authoritarian perspective" as Ogan (1982) argued, because there is an urgent need for development in the country, and opposing voices are not important in this perspective. Finally, the concept should be evaluated, conceptualized, 
Jurnal Komunikasi

Malaysian Journal of Communication

Jilid 32 (1) 2016: 289-310

defined, and critically scrutinized by a group of experts including mass communication scholars in order to come out a more appropriate version, which is fully applicable to Somali context.

\section{BIODATA AUTHOR}

Ismail Sheikh Yusuf Ahmed is a full-time Teaching Assistant at the Department of Mass Communication, Qatar University. He is currently teaching two courses namely Media \& Society and First Year Seminar. His recent publications appeared in Malaysian Journal of Communication, SEARCH Journal, and Journal of Asian Pacific Communication, among others. He can be reached at iahmed@qu.edu.qa. 


\section{REFERENCES}

Anand, V. E. (2014). Development Journalism: A Catalyst for Positive Change. Procedia Social and Behavioral Sciences, 157, 210-225. http://doi.org/10.1016/j.sbspro.2014.11.024

Banda, F. (2007). An appraisal of the applicability of development journalism in the context of public service broadcasting (PSB). Communicatio: South African Journal for Communication Theory and Research, 33(2), 154-170. http://doi.org/10.1080/02500160701685466

Barrow, R. (1988). The role of media in disseminating the Arabic language in Somalia. Kartoum: Unpublished thesis, Khartoum International institute for Arabic Language.

Bessette, G. Introduction to development communication (2004). Penag \& Ontario: Internationl Communication Centre \& Southbound.

Boafo, S. K. (1985). Utilizing Development Communication Strategies in African Societies: A Critical Perspective (Development Communication in Africa). International Communication Gazette, 35(2), 83-92. http://doi.org/10.1177/001654928503500202

Curtis, D. (2000). Broadcasting peace: an analysis of local media post-conflict peacebuilding projects in Rwanda and Bosnia. Canadian Journal of Development Studies, 21(1), 141-166. http://doi.org/10.1080/02255189.2000.9669886

Domatob, J. K., \& Hall, S. W. (1983). Development Journalism in Black Africa. Gazette, 40(3), 9-33. 
Edeani, D. O. (1993). Role of development journalism in Nigeria's development. International Communication Gazette, 52(2), 12-143. http://doi.org/10.1177/001654929305200204

Green, G. P., \& Goetting, A. (Eds.). (2010). Mobilizing communities: Asset buidling as a community development strategy. Philadelphia: Temple University Press.

McPhail, T. L. (2009). Development Communication: Reframing the role of the media. In T. L. McPhail (Ed.), Development Communication: Reframing the role of the media. West Sussex: Wiley-Blackwell.

Mefalopulos, P. (2009). Development communication sourcebook: Broadening the boundaries of communication. Washington: The World Bank.

Ministry of Information and National Guidance (MING). (1974). National campaign for illiteracy eradication and rural development. Mogadishu: Government Printing House.

Müller, A., Mitchell, P., \& Feek, W. (2007). World congress on communication fro development: Lessons, challenges and the way forward. Washington: World Bank.

Odhiambo, L. O. (1991). Development Journalism in Africa: Capitulation of the Fourth Estate? African Media Review, 5(2), 17-29.

Ogan, C. L. (1982). Development journalism/communication: The status of the concept. International Communication Gazette, 29(1-2), 3-13. http://doi.org/10.1177/001654928202900101 
Pate, U. A., \& Dauda, S. (2013). Media and socio economic development in Northern Nigeria. Jurnal Komunikasi: Malaysian Journal of Communication, 29(1), 1-19.

Skjerdal, T. S. (2011). Development journalism revived: The case of Ethiopia. Ecquid Novi: African Journalism Studies, 32(2), 58-74. http://doi.org/10.1080/02560054.2011.578879

Smith, D. (2012). Somalia chooses new leader in presidential elections. Retrieved April 22, 2014, from http://www.theguardian.com/world/2012/sep/10/somalia-chooses-newpresident-elections

Sparks, C. (2007). Development, globalizaiton and the mass media. London: Sage Publications.

Upsall, K. C. (2014). State Building in Somalia in the Image of Somaliland : A Bottom-Up Approach. Student Pulse, 6(3), 1-10. Retrieved from http://www.studentpulse.com/a?id=880

Wong, K. (2004). Asian-Based Development Journalism and Political Elections: Press Coverage of the 1999 General Elections in Malaysia. International Communication Gazette, 66(1), 25-40. http://doi.org/10.1177/0016549204039940

Yusuf, F., Ibrahim, F., \& Aminah, W. (2012). Agricultural Radio talks and drama: Malaysian early development experience. Jurnal Komunikasi: Malaysian Journal of Communication, 28(1), 77-88. 